\title{
Synergistic effects of melphalan and Pinus kesiya Royle ex Gordon (Simaosong) extracts on apoptosis induction in human cancer cells
}

\author{
Natthida Weerapreeyakul ${ }^{1 *}$, Sasipawan Machana ${ }^{2}$ and Sahapat Barusrux ${ }^{3}$
}

\begin{abstract}
Background: This study aims to determine the synergistic effects of the chemotherapeutic drug melphalan and the phytoconstituents extracted from Pinus kesiya Royle ex Gordon (Simaosong) in human cancer cells.

Methods: P. kesiya twigs extracted from $50 \%$ ethanol-water were evaluated alone $(6-500 \mathrm{\mu g} / \mathrm{mL})$ and in combination with melphalan $(0.75-15 \mu \mathrm{g} / \mathrm{mL})$. The cytotoxic effects of single extract or extract and melphalan combination were examined by a neutral red assay to investigate their antiproliferative and apoptosis induction effects in the U937 and HepG2 cell lines. Nuclei morphological change and DNA fragmentation were examined by DNA nuclei staining with 4'6-diamidino-2-phenylindole (DAPI) and agarose gel electrophoresis, respectively. The chemical constituents of the $P$. kesiya extract were assessed using gas chromatography-mass spectrometry (GC-MS) analysis. The synergistic effects of different $I C_{50}$ ratios of the P. kesiya extract and melphalan combination were analyzed in each cancer cell line. The dose reduction index (DRI) was calculated to determine the extent of concentration reduction in the combination treatment compared with the concentration of each single treatment.
\end{abstract}

Results: The $I C_{50}$ ratios for melphalan to $P$. kesiya extract that caused $75 \%$ antiproliferation could be reduced after combination. This response was greater in the U937 cells than in the HepG2 cells (all $P<0.001$ ). Melphalan and $P$. kesiya extract had a similar effect on apoptosis induction both singly and in combination. P. kesiya extract synergized the antiproliferation and apoptosis induction effects of melphalan.

Conclusions: Combining the P. kesiya extract with melphalan reduced toxicity while retaining the therapeutic efficacy of melphalan.

\section{Background}

Specific and selective apoptosis induction in targeted chemotherapy is limited due to multidrug resistance and intolerably severe side effects $[1,2]$. Synergistic combinations of two or more agents could overcome the toxicity and side effects associated with the high doses of chemotherapeutic drugs in monotherapy [3]. Several herbal plant extracts are rich sources of bioactive constituents that inhibit, reverse, or retard tumorigenesis [3, 4].

\footnotetext{
*Correspondence: natthida@kku.ac.th

${ }^{1}$ Faculty of Pharmaceutical Sciences, Khon Kaen University, Khon Kaen 40002, Thailand

Full list of author information is available at the end of the article
}

Additionally, some research on herbal synergistic action indicates that the whole herb produces a better effect than any single isolated active ingredient $[5,6]$.

The rosin of Pinus kesiya Royle ex Gordon (Simaosong) contains szemaoenin (diterpenoid) isopimaric acid, abiet-13(14)-en-8,12-epoxy-18-oic acid, abiet-8,11,13trien-15-hydroxy-18-oic acid, pimarol, isopimarol, abiet8,11,13-trien-18-oic acid, and 15-hydroxyabietic acid [7]. The main compounds found in P. kesiya turpentine are $\alpha$ - and $\beta$-pinene [8]. The needle oil is rich in $\alpha$ - and $\beta$-pinene, citronellol, bornyl acetate, $\beta$-phellandrene, camphene, and $\beta$-caryophyllene [9]. The needles of $P$. kesiya contain dichlorobenzene isomer, 1,4-cineol, 
$\alpha$-terpinene, o-cimene and imonene enantiomers [10, 11 , and monoterpenes [12].

P. kesiya is used to relieve flatulence, stomachache, and cough in complementary and alternative medicine [13]. The $50 \%$ ethanol-water crude extract of the woody twigs of $P$. kesiya has an apoptotic-induction effect on both the human hepatocellular carcinoma HepG2 and the human leukemic U937 cell lines because of its cytotoxicity [14, 15]. Many studies indicate that this effect arises from the whole crude extract with its lower activity of isolated individual compounds [3-6]. The synergistic effect of the whole extract of $P$. kesiya plus the chemotherapeutic drug melphalan is of interest as it may expand the use of this herbal plant. Melphalan is an alkylating anticancer drug, leading to DNA cross-linking, DNA damage, and finally apoptosis of cancer cells [16]; however, melphalan resistance and highly toxic side effects in other tissues limit its use $[17,18]$. We hypothesized that plant extracts that exhibited an anticancer activity in vitro might enhance the antiproliferative activity of melphalan, which would permit the use of a lower dosage and reduced side effects. This study aims to determine the synergistic effects of $P$. kesiya and melphalan phytoconstituents in human cancer cells.

\section{Methods}

\section{Plant extraction}

P. kesiya woody twigs were collected and taxonomically authenticated by Assistant Professor Thaweesak Thitimetharoach. The species of samples were determined using the Flora of Thailand [19] and the Thai Forest Bulletin [20]. The voucher (TT-OC-SK-910) was deposited at the Herbal Herbarium, Faculty of Pharmaceutical Sciences, Khon Kaen University, Khon Kaen Province, Thailand. The $50 \%$ ethanol-water extract of $P$. kesiya twig was prepared as previously reported $[14,15]$. Dried plants were cut and macerated with $50 \%$ ethanol-water (1 kg:6 L) for 7 days with occasional manual shaking. The solvent was filtered, distilled by a rotary evaporator (RV 8 V, IKA, Germany) below $40^{\circ} \mathrm{C}$, and freeze-dried to obtain the crude extract. The percent yield of the $50 \%$ ethanol-water extract of $P$. kesiya was $4.3 \%$. Stock solution of $P$. kesiya extract was freshly prepared in dimethyl sulfoxide (DMSO) to make $100 \mathrm{mg} / \mathrm{mL}$ stock solution and further diluted with culture media to create a working solution (10 to $500 \mu \mathrm{g} / \mathrm{mL}$ ).

Gas chromatography-mass spectrometry (GC-MS) analysis GC-MS analysis was performed as described by Weerapreeyakul et al. [21] on an Agilent $6890 \mathrm{~N}$ gas chromatograph (Agilent Technologies, China) coupled to an Agilent $5973 \mathrm{~N}$ mass selective detector (Agilent Technologies, USA) to determine the extract composition for further standardization. Capillary GC analysis was performed using a DB- $5 \mathrm{~ms}(3 \mathrm{~m} \times 0.25 \mathrm{~mm}$ id, $0.25 \mu \mathrm{m})$ capillary column from Agilent Technologies (J\&W Scientific, USA) with helium as the carrier gas. The column initially flowed at $80{ }^{\circ} \mathrm{C}$ for $6 \mathrm{~min}$ at a rate of $2 \mathrm{~mL} / \mathrm{min}$ and an average velocity of $52 \mathrm{~cm} / \mathrm{s}$. The temperature was raised to $280{ }^{\circ} \mathrm{C}$ (at a rate of $5{ }^{\circ} \mathrm{C} / \mathrm{min}$ ) for $24 \mathrm{~min}$. The total runtime was $70 \mathrm{~min}$. The injector temperature was maintained at $250^{\circ} \mathrm{C}$ and the injection volume was set at $2.0 \mu \mathrm{L}$ in the splitless mode. The interface temperature was held at $280^{\circ} \mathrm{C}$. Mass spectra were scanned from $\mathrm{m} / \mathrm{z}$ 50.0 to $\mathrm{m} / \mathrm{z} 500.0$ at a rate of 1.5 scans/s with a threshold of 150. The electron impact ionization energy was $70 \mathrm{eV}$. The chemical components of the crude extracts were identified from the chromatograms and mass spectra using the Wiley 7 N.l database (Agilent Technologies, USA).

\section{Cell culture}

The human leukemic (U937) cell line was cultured in RPMI 1640. The human hepatocellular carcinoma (HepG2) cell line and normal African green monkey kidney epithelial (Vero) cell line were cultured in DMEM (GIBCO, Invitrogen Corporation, USA). Both media were supplemented with $10 \%$ fetal bovine serum (GIBCO, Invitrogen Corporation), 100 units/mL penicillin and $100 \mu \mathrm{g} / \mathrm{mL}$ streptomycin (GIBCO, Invitrogen Corporation). The cells were cultured at $37{ }^{\circ} \mathrm{C}$ in a humidified atmosphere containing $5 \% \mathrm{CO}_{2}$.

\section{Antiproliferative effect}

The antiproliferative activity of the $P$. kesiya extract in the leukemia (U937), hepatocellular carcinoma (HepG2), and normal (Vero) cell lines was assessed by neutral red assay $[14,15]$. Briefly, $100 \mu \mathrm{L}$ of U937 cells at a density of $5 \times 10^{5}$ cells $/ \mathrm{mL}$ and $100 \mu \mathrm{L}$ of HepG2 or Vero cells at a density of $3 \times 10^{5}$ cells $/ \mathrm{mL}$ were independently seeded in 96-wells plates and incubated for $24 \mathrm{~h}$. After cell growth, cells were treated with various concentrations (10 to $500 \mu \mathrm{g} / \mathrm{mL}$ ) of the $P$. kesiya crude extract or melphalan (purity 95 \%, Sigma-Aldrich Chemie GmbH, Germany) dissolved in DMSO (United States Biological, USA). The maximum final concentration of the compound was $500 \mu \mathrm{g} / \mathrm{mL}$ to maintain $1 \% \mathrm{v} / \mathrm{v}$ DMSO with a cytotoxicity $<10 \%$ compared with the untreated cells. After treated cells were exposed to the test compound for $24 \mathrm{~h}$, cells were stained directly with a final concentration of $50 \mu \mathrm{g} /$ $\mathrm{mL}$ neutral red dye (Sigma Chemicals Co., USA) and incubated for another $2 \mathrm{~h}$. The neutral red stained viable cells were dissolved by $0.33 \%$ hydrogen chloride in isopropanol and detected using a colorimetric-based method. The absorbance was measured at 520 and $650 \mathrm{~nm}$ (reference wavelength) by a spectromicroplate reader (TECAN, 
Grödig, Austria). A plot of percentage cytotoxicity vs. test compound concentration was used to calculate the $\mathrm{IC}_{50}$.

\section{Apoptosis induction effect \\ Nuclei morphological study by 4'6-diamidino-2-phenylindole (DAPI) staining assay}

The apoptosis effect of the plant crude extracts was primarily determined by fluorescent dye staining and DAPI to identify the condensation and fragmentation of nuclear DNA [14, 15]. Briefly, the cancer cells (HepG2 or U937) were treated with various concentrations of the test compounds (6 to $500 \mu \mathrm{g} / \mathrm{mL}$ of $P$. kesiya and 0.75 to $15 \mu \mathrm{g} / \mathrm{mL}$ of melphalan) for $24 \mathrm{~h}$, after which the culture medium was removed and the cells were washed with fresh medium. Cells were then fixed by cold methanol. DAPI dye (Sigma-Aldrich Chemie GmbH, Germany) was then added to stain the nuclei DNA for $1 \mathrm{~h}$. The excess dye was removed and 1X PBS ( $\mathrm{pH} 7.4$; $10 \mathrm{mM}$ ) was added to glycerin (at a 1:1 ratio). The DAPI staining assay was performed in triplicate in independent experiments. An inverted fluorescence microscope (Nikon eclipse 80i, Kanagawa, Japan) was used to record images of the DAPI staining. The average percentage of apoptotic cells was calculated from three independent wells with 10 eye views per well under the inverted fluorescence microscopy at a magnitude of $40 \times$.

\section{Analysis of DNA fragmentation}

DNA fragmentation was analyzed [14, 15]. Briefly, after cancer cells were treated with various concentrations of $P$. kesiya extracts $(60,150,300,450$, and $500 \mu \mathrm{g} / \mathrm{mL})$ and melphalan $(15 \mu \mathrm{g} / \mathrm{mL})$ for $24 \mathrm{~h}$, they were collected and washed with fresh medium. Then, the cell suspension was transferred to microcentrifuge tubes and centrifuged (Daihan Scientific, Seoul, Korea) at $300 \times g$ for 5 min to collect the cell pellet. The DNA in the cell pellet was extracted using a FlexiGene DNA kit (QIAGEN GmbH, Germany) then $2 \mu \mathrm{g}$ of the DNA was analyzed using electrophoresis on $2 \%$ agarose gels (Bio-Rad, USA) containing $0.1 \mathrm{mg} / \mathrm{mL}$ ethidium bromide (AppliChem, USA). DNA was mixed with loading dye (SibEnzyme Ltd., Russia) and the gel electrophoresed in 0.5X Tris-Borate-EDTA buffer ( $\mathrm{pH} 8.3 ; 40$ mMTris base, $45 \mathrm{mM}$ boric acid, $1 \mathrm{mM}$ EDTA; Sigma-Aldrich Chemie $\mathrm{GmbH}$, Germany) at $250 \mathrm{~V}$ for $1 \mathrm{~min}$ and $20 \mathrm{~V}$ for $4 \mathrm{~h}$. After electrophoresis, the DNA fragments were analyzed by In Genius L gel documentation (Syngene, USA).

\section{Enhancement of anticancer effect of $P$. kesiya extract in vitro}

The enhanced chemosensitivity of melphalan combined with P. kesiya on the U937 and HepG2 cell lines was determined as per Chou and Talalay [22]. The antiproliferation assay on the melphalan and $P$. kesiya extract combination treatment against the HepG2 cancer cell line after $24 \mathrm{~h}$ was performed using the same method as for melphalan or P. kesiya extract alone. The cells were treated with the $P$. kesiya extract and melphalan was added subsequently. Different concentrations of the $P$. kesiya extract and melphalan combination treatment were used (Table 1). Briefly, the melphalan concentration was fixed at $1 \times \mathrm{IC}_{50}$ and the $P$. kesiya concentration was varied at $0.02,0.05,0.1,0.2,0.5,1,1.5$, and $2 \times \mathrm{IC}_{50}$ in the U937 and HepG2 cell lines. In another series, the $P$. kesiya extract concentration was fixed at $1 \times \mathrm{IC}_{50}$ and the melphalan concentration was varied at $0.05,0.1,0.2,0.5,1,1.5$, and $2 \times \mathrm{IC}_{50}$ in both cancer cell lines. The maximum concentration that could be used in the experiment to maintain the percentage DMSO at less than $1 \% \mathrm{v} / \mathrm{v}$ was $500 \mu \mathrm{g} / \mathrm{mL}$, instead of a $2 \times \mathrm{IC}_{50}$ concentration of $P$. kesiya $(600 \mu \mathrm{g} / \mathrm{mL})$, the concentration used in this study was only $500 \mu \mathrm{g} / \mathrm{mL}$. After $24 \mathrm{~h}$ exposure, the percentage of antiproliferation for each treatment was calculated.

The combined effects were analyzed to determine whether the enhanced growth inhibitory effect was antagonistic, additive, or synergistic. The combination index (CI) was calculated (adapted from the multipledrug effect analysis based on the median effect principle and the isobologram technique developed by Chou [22] and Eid et al. [23]). The CI took into account both the potency and shape of the dose-effect curve, which is given by Eq. (1):

$$
\mathrm{CI}=\frac{(\mathrm{D})_{1}}{\left(\mathrm{D}_{\mathrm{X}}\right)_{1}}+\frac{(\mathrm{D})_{2}}{\left(\mathrm{D}_{\mathrm{X}}\right)_{2}}
$$

$\mathrm{CI}>1,=1$, and $<1$ correspond to synergism, addition, and antagonism, respectively. The denominators $\left(D_{x}\right)_{1}$ and $\left(D_{x}\right)_{2}$ are the doses of a single treatment of the first and second compound designated as $\mathbf{1}$ and 2, respectively. Additionally, (D) $)_{1}$ and $(\mathrm{D})_{2}$ are the doses of the compounds $\mathbf{1}$ and $\mathbf{2}$ in the combination treatment that exhibited $\mathrm{x} \%$ antiproliferation.

The calculated dose reduction index (DRI) was used to determine the extent of dose reduction in the combination treatment compared with the dose of each single treatment. For the combination effect, DRI was defined as $\quad \mathrm{DRI}_{1}=\left(\mathrm{D}_{\mathrm{X}}\right)_{1} /(\mathrm{D})_{1}$ and $\mathrm{DRI}_{2}=\left(\mathrm{D}_{\mathrm{X}}\right)_{2} /(\mathrm{D})_{2}$. The relationship between DRI and CI was represented as: $\mathrm{CI}=1 / \mathrm{DRI}_{1}+1 / \mathrm{DRI}_{2}$.

The same antiproliferation experiment was performed on the normal Vero cells to provide a comparison to determine the cytotoxic effect of combining the compounds against the normal cells. The synergistic apoptotic effects of the combination of $P$. kesiya extract and melphalan were evaluated against the U937 and HepG2 cells by DAPI staining and DNA fragmentation assay. 


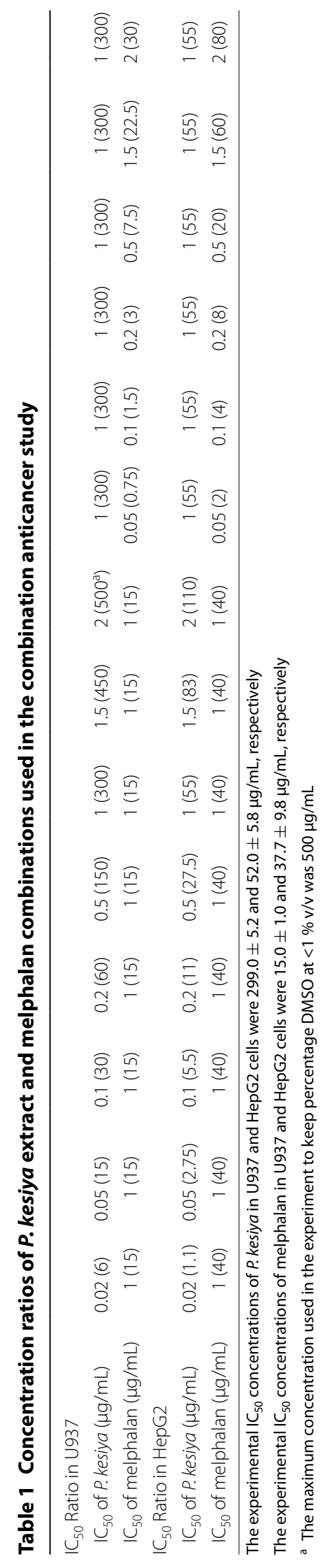


Table 2 Antiproliferation of $P$. kesiya extract and melphalan combination in U937, HepG2, and Vero cell lines

\begin{tabular}{|c|c|c|c|c|}
\hline \multicolumn{2}{|l|}{$I C_{50}$ Ratio } & \multicolumn{3}{|c|}{$\%$ Antiproliferation } \\
\hline P. kesiya & Melphalan & U937 & HepG2 & Vero \\
\hline 0 & 1 & 50 & 50 & $50^{\mathrm{a}}$ \\
\hline 1 & 0 & 50 & 50 & Inactive ${ }^{b}$ \\
\hline 1 & 1 & $100 \pm 7.0$ & $95.7 \pm 12.2$ & $6.8 \pm 1.9$ \\
\hline 0.02 & 1 & $46.0 \pm 5.7$ & $\mathrm{Nd}$ & $\mathrm{Nd}$ \\
\hline 0.05 & 1 & $59.8 \pm 5.3$ & $\mathrm{Nd}$ & $\mathrm{Nd}$ \\
\hline 0.1 & 1 & $76.6 \pm 13.5$ & $\mathrm{Nd}$ & $1.0 \pm 3.5$ \\
\hline 0.2 & 1 & $79.3 \pm 3.7$ & $43.7 \pm 2.9$ & $4.0 \pm 6.1$ \\
\hline 0.5 & 1 & $100 \pm 7.0$ & $82.1 \pm 4.9$ & $7.3 \pm 1.9$ \\
\hline 1.5 & 1 & $100 \pm 2.2$ & $93.4 \pm 1.6$ & $16.4 \pm 4.7$ \\
\hline 2 & 1 & $100 \pm 11.3$ & $100 \pm 3.1$ & $24.7 \pm 9.1$ \\
\hline 1 & 0.05 & $46.8 \pm 9.5$ & $34.2 \pm 4.4$ & $\mathrm{Nd}$ \\
\hline 1 & 0.1 & $51.8 \pm 5.5$ & $46.0 \pm 9.1$ & $\mathrm{Nd}$ \\
\hline 1 & 0.2 & $73.0 \pm 4.2$ & $60.7 \pm 16.4$ & $0 \pm 3.3$ \\
\hline 1 & 0.5 & $76.4 \pm 3.6$ & $65.1 \pm 9.1$ & $1.8 \pm 1.2$ \\
\hline 1 & 1.5 & $100 \pm 2.0$ & $100 \pm 10.5$ & $8.6 \pm 1.4$ \\
\hline 1 & 2 & $100 \pm 3.4$ & $100 \pm 4.9$ & $9.5 \pm 1.9$ \\
\hline
\end{tabular}

Two-way ANOVA detected significant antiproliferative activity differences among various $\mathrm{IC}_{50}$ ratios $(P<0.001)$ and among various cell lines $(P<0.001)$. A significant two-way interaction was observed between $\mathrm{IC}_{50}$ ratio and various cell lines $(P<0.001)$

$N d$ not determined

${ }^{\text {a }} \mathrm{IC}_{50}$ value of melphalan in Vero cells equals $59.9 \pm 3.2 \mu \mathrm{g} / \mathrm{mL}$

b Inactive when $\mathrm{IC}_{50}$ of $P$. kesiya in Vero cells was $>500 \mu \mathrm{g} / \mathrm{mL}$

\section{Statistical analysis}

Experiments were performed in triplicate and the results were expressed as a mean \pm standard deviation from three independent experiments. Statistical analysis was performed by IBM SPSS Statistics 17.0 (SPSS Inc., Chicago, IL, USA). A two-way analysis of variance (ANOVA) test followed by Fisher's least significant difference test for multiple comparisons of independent experiments were used to determine the effective enhancement of the inhibition growth by $P$. kesiya and melphalan in various cell lines. The significance level was set at $P<0.05$. Statistical differences of percentage apoptotic cells between the $P$. kesiya treated group and the positive control group were compared by one-way ANOVA followed by Tukey's honest significant difference test with a significance level of $P<0.05$.

\section{Results}

Antiproliferative effects of $P$. kesiya extract and melphalan singly versus in combination on U937 and HepG2 cell lines The antiproliferative effects of $P$. kesiya extract and melphalan singly or in combination were investigated in U937 and HepG2 cell lines. The $\mathrm{IC}_{50}$ values of $P$. kesiya in U937 and HepG2 were $299.0 \pm 5.2 \mu \mathrm{g} / \mathrm{mL}$ and
$52.0 \pm 5.8 \mu \mathrm{g} / \mathrm{mL}$, respectively. The $\mathrm{IC}_{50}$ values of melphalan in U937 and HepG2 were $15.0 \pm 1.0 \mu \mathrm{g} / \mathrm{mL}$ and $37.7 \pm 9.8 \mu \mathrm{g} / \mathrm{mL}$, respectively. Both melphalan and $P$. kesiya extract caused significantly greater antiproliferation than was observed in untreated cancer cells (control). P. kesiya extract exerted potent antiproliferation in the HepG2 cells at an $\mathrm{IC}_{50}$ value of $52.0 \pm 5.8 \mu \mathrm{g} /$ $\mathrm{mL}$. $P$. kesiya extract had a stronger selectivity against the two cancer cell lines than melphalan. A significant enhanced antiproliferative effect occurred with the combination when treating human U937 and HepG2 cell lines (Table 2). A two-way ANOVA was conducted that examined the effect of $\mathrm{IC}_{50}$ ratio and cell types on percentage antiproliferation. There was a statistically significant interaction between the effects of $\mathrm{IC}_{50}$ ratio and cell types on percentage antiproliferation, $F(26$, $84)=42.654, P<0.001$. A two-way ANOVA detected significant differences in the antiproliferative activity of the various $\mathrm{IC}_{50}$ ratios (all $P<0.001$ ) and among the various cell lines $(P<0.001)$. Significantly higher antiproliferative activities were observed at $P$. kesiya to melphalan concentration ratios of $0.2: 1,0.5: 1,1: 1$, $1.5: 1,2: 1,1: 0.2,1: 0.5,1: 1.5$, and $1: 2$ compared with normal Vero cells $(P<0.001)$. When the concentration of melphalan was constant, an enhanced antiproliferative effect was observed at $P$. kesiya to melphalan concentration ratios of $0.05: 1$ and $0.5: 1$ in the U937 and HepG2 cell lines, respectively. Alternatively, when $P$. kesiya was constant, the enhanced antiproliferative effect was observed at melphalan to P. kesiya concentration ratios of $0.1: 1$ and $0.2: 1$ in the U937 and HepG2 cell lines, respectively.

Melphalan alone exhibited strong antiproliferation in normal Vero cells at an $\mathrm{IC}_{50}$ value of $59.9 \pm 3.2 \mu \mathrm{g} / \mathrm{mL}$, while $P$. kesiya extract alone was inactive in normal Vero cells. When treating the Vero cells, the antiproliferation of the combination treatment was $<25 \%$ when the concentration of melphalan was constant (Table 2). The result showed an antagonistic effect of $P$. kesiya extract on the antiproliferation of melphalan in Vero cells. In the presence of a $1 \times \mathrm{IC}_{50}$ concentration of $P$. kesiya, the concentration of melphalan used could be as high as $2 \times \mathrm{IC}_{50}$, producing only $9.5 \pm 1.9 \%$ antiproliferation against Vero cells.

\section{Synergistic effect of melphalan and $P$. kesiya extract combination analyzed in U937 leukemic and HepG2 hepatocellular carcinoma cell lines}

The CIs of the combined effect of P. kesiya and melphalan in the U937 and HepG2 cell lines at $\mathrm{IC}_{75}$ and $\mathrm{IC}_{90}$ values are presented in Table 3 and Fig. 1. Our results indicated that the combination of $P$. kesiya and melphalan exhibited high synergistic effects in U937 and HepG2 
Table 3 Dose reduction index (DRI) and combination index (CI)

\begin{tabular}{|c|c|c|c|c|c|}
\hline \multirow[t]{2}{*}{$\%$ Antiproliferation } & \multirow[t]{2}{*}{ Cell lines } & \multirow[t]{2}{*}{ Combination treatment } & \multicolumn{2}{|l|}{ DRI } & \multirow[t]{2}{*}{$\mathrm{Cl}$} \\
\hline & & & P. kesiya & Melphalan & \\
\hline \multirow[t]{4}{*}{$90 \%\left(I C_{90}\right)$} & U937 & Fixed $[$ P. kesiya $]=I C_{50}$ & 2.3 & 7.8 & 0.56 \\
\hline & & Fixed $[$ melphalan $]=I C_{50}$ & 6.5 & 5.5 & 0.33 \\
\hline & HepG2 & Fixed $[$ P. kesiya $]=I C_{50}$ & 2.0 & 3.6 & 0.79 \\
\hline & & Fixed $\left[\right.$ melphalan] $=I C_{50}$ & 2.4 & 3.2 & 0.74 \\
\hline \multirow[t]{4}{*}{$75 \%\left(I C_{75}\right)$} & U937 & Fixed $[$ P. kesiya $]=I C_{50}$ & 1.8 & 8.7 & 0.66 \\
\hline & & Fixed $\left[\right.$ melphalan] $=I C_{50}$ & 9.1 & 3.8 & 0.37 \\
\hline & HepG2 & Fixed $[$ P. kesiya $]=I C_{50}$ & 1.6 & 3.8 & 0.90 \\
\hline & & Fixed $\left[\right.$ melphalan] $=I C_{50}$ & 2.7 & 2.4 & 0.79 \\
\hline
\end{tabular}

$\mathrm{DRI}$ and $\mathrm{Cl}$ of the combination treatment of $P$. kesiya/melphalan in U937 or in HepG2 cells at the concentrations that produced 90 and $75 \%$ antiproliferation

a U937 fixed $P$. kesiya

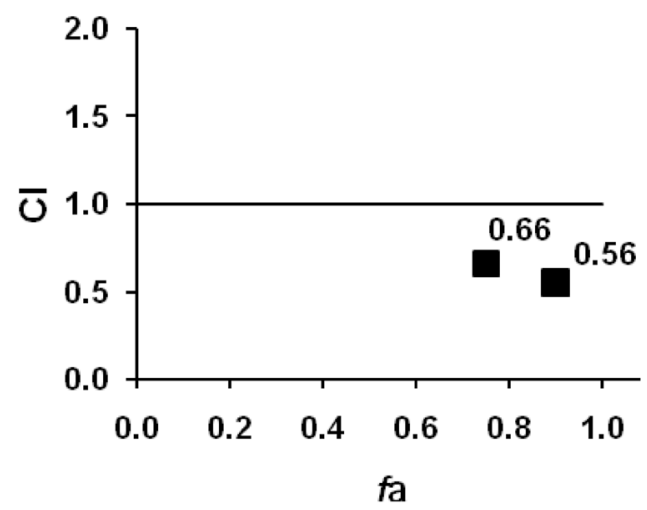

C HepG2 fixed P. kesiya

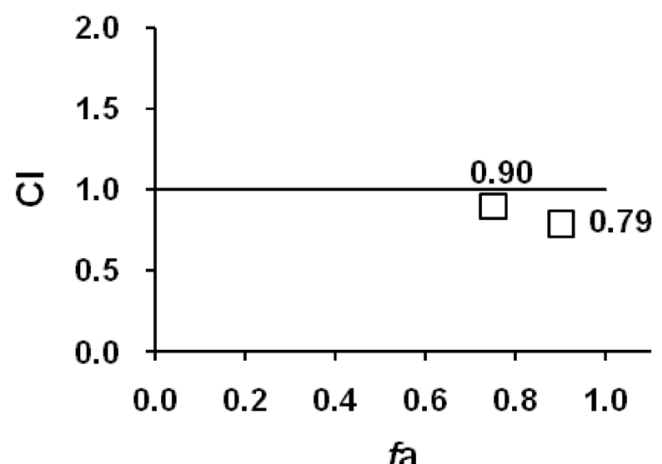

b U937 fixed melphalan

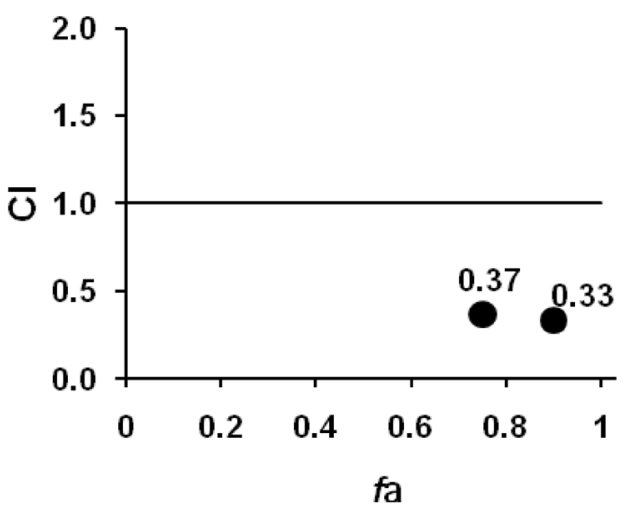

d HepG2 fixed melphalan

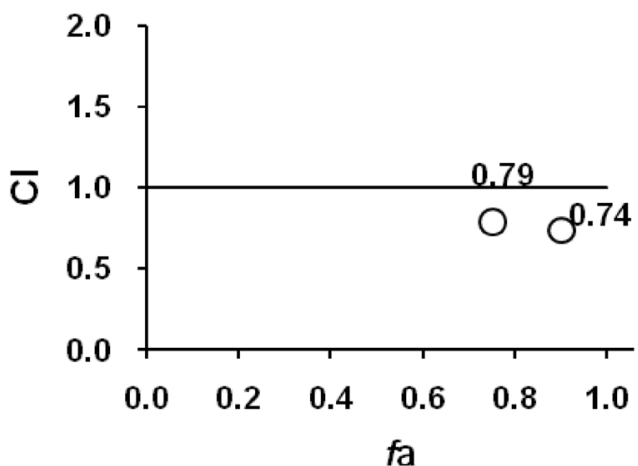

Fig. 1 Isobolograms of the plot between combination index (CI) and fa in U937 (black symbol) and HepG2 (white symbol). fa = fraction affected by D (i.e., percentage antiproliferation/100). Isobolograms of the combination of compounds when P. kesiya was fixed (a, $\mathbf{c}$; square), and when melphalan was fixed (b, d; circle) in each cancer cell lines 
cells at concentrations producing 75 and $90 \%$ antiproliferation $\left(\mathrm{IC}_{75}\right.$ and $\left.\mathrm{IC}_{90}\right)$. As observed from the higher synergistic effect (low CI value), the combination therapy was more effective on the U937 cells than on the HepG2 cells.

\section{Extent of dose reduction in the combination treatment compared with single doses of each treatment}

Table 3 shows the decreased concentration of melphalan or $P$. kesiya extract in the combination therapy to produce 90 and $75 \%$ antiproliferation in U937 cells and HepG2 cells. The concentration of melphalan (when combined with a fixed concentration of $P$. kesiya extract) necessary to inhibit cancer growth by $90 \%$ $\left(\mathrm{IC}_{90}\right)$ represents a 7.8- and 3.6-fold decrease in U937 and HepG2 cells, respectively. By comparison, the concentration of $P$. kesiya extract (when combined with a fixed concentration of melphalan) needed for the $\mathrm{IC}_{90}$ represents a 6.5- and 2.4-fold decrease in U937 and HepG2 cells, respectively. A similar DRI trend (i.e., a greater melphalan dose reduction) for U937 cells compared with HepG2 cells was observed at $75 \%$ antiproliferation. Dose reduction also depended on the type of cancer cells: 90 and $75 \%$ cell death occurred when the $P$. kesiya extract concentration was fixed. The doses for melphalan per dose of $P$. kesiya extract could be reduced in the U937 cells $(10.55: 300=0.04: 1$ and $6.6: 300=0.02: 1$ ) more than in the HepG2 cells $(33.7: 55.0=0.61: 1$ and $23.7: 55.0=0.43: 1)$. The synergistic effect appears to be greater for the melphalan because a greater potential dose reduction could be achieved; thus, melphalan concentrations could be significantly reduced.

\section{Apoptotic induction effect of single treatments and of $P$. kesiya extract and melphalan combination treatment} Apoptosis induction by P. kesiya extract and melphalan when used singly or in combination was evaluated in HepG2 and U937 cell lines using a method based on the DAPI staining assay (Table 4) and DNA fragmentation assays (Fig. 2). In the control group, the nuclei were roundish and homogeneously stained by DAPI; in contrast, the apoptotic nuclei in the treated U937 and HepG2 cells were irregularly shaped, small, detached, and had apoptotic bodies. At a $1 \times \mathrm{IC}_{50}$ concentration, P. kesiya extract induced $42.5 \pm 4.8$ and $39.7 \pm 2.6 \%$ apoptosis in the U937 and HepG2 cells, respectively; melphalan induced $43.1 \pm 16.3$ and $53.0 \pm 6.1 \%$ apoptosis, respectively. The combination therapy of P. kesiya extract and melphalan was significantly more effective in inducing apoptosis against U937 and HepG2 cells.

DNA fragmentation was determined according to whether the synergistic apoptosis induction in both
Table 4 Effects of $P$. kesiya and melphalan on apoptosis induction in U937 and HepG2 cells

\begin{tabular}{|c|c|c|c|}
\hline \multicolumn{2}{|l|}{$\mathrm{IC}_{50}$ ratio } & \multicolumn{2}{|c|}{$\%$ Apoptotic cells } \\
\hline$I C_{50}$ of $P$. kesiya & $\mathrm{IC}_{50}$ of Melphalan & U937 & HepG2 \\
\hline 0 & 1 & $43.1 \pm 16.3$ & $53.0 \pm 6.1$ \\
\hline 1 & 0 & $42.5 \pm 4.8^{b}$ & $39.7 \pm 2.6^{a}$ \\
\hline 1 & 1 & $100^{\mathrm{a}}$ & $100^{a}$ \\
\hline 0.1 & 1 & $77.0 \pm 1.9^{a}$ & $66.7 \pm 3.1^{\mathrm{a}}$ \\
\hline 0.2 & 1 & $100^{\mathrm{a}}$ & $74.9 \pm 12.3^{a}$ \\
\hline 0.5 & 1 & $100^{\mathrm{a}}$ & $92.8 \pm 1.3^{\mathrm{a}}$ \\
\hline 1.5 & 1 & $100^{a}$ & $98.3 \pm 3.0^{\mathrm{a}}$ \\
\hline 2 & 1 & $100^{\mathrm{a}}$ & $100^{\mathrm{a}}$ \\
\hline 1 & 0.05 & $38.6 \pm 6.1^{\mathrm{a}}$ & $62.4 \pm 3.2^{\mathrm{a}}$ \\
\hline 1 & 0.1 & $48.4 \pm 3.8^{\mathrm{a}}$ & $87.9 \pm 3.3^{\mathrm{a}}$ \\
\hline 1 & 0.2 & $61.3 \pm 3.3^{\mathrm{a}}$ & $90.3 \pm 6.0^{a}$ \\
\hline 1 & 0.5 & $100^{a}$ & $100^{\mathrm{a}}$ \\
\hline 1 & 1.5 & $100^{a}$ & $100^{a}$ \\
\hline 1 & 2 & $100^{a}$ & $100^{a}$ \\
\hline
\end{tabular}

One-way ANOVA of percentage apoptotic cells compared with single treatment by melphalan at $1 \times \mathrm{IC}_{50}$ in cancer cells

a Significant difference $(P<0.001)$

b Non-significant difference $(P \geq 0.001)$

cancer cells occurred toward the late stage of apoptosis, as previously observed for single therapy [15]. The combined treatment of $P$. kesiya with melphalan resulted in DNA laddering in both the HepG2 and U937 cells compared with the control cells (Fig. 2).

\section{GC-MS analysis of $P$. kesiya extract}

GC-MS analysis of $P$. kesiya extract was performed to obtain its characteristic fingerprint (Table 5). The GC peaks obtained were used for further chemical constituent identification and revealed several compounds:podocarpa-8,11,13-trien-15-oic acid, neopine, rosin acid, pimaric acid, oleic acid, pyrocatecol, and vanillin (Table 5).

\section{Discussion}

To our knowledge, this is the first report of a synergistic effect of $P$. kesiya extract on melphalan anticancer activity via the apoptosis induction mechanism in vitro. The U937 cells were only sensitive to melphalan, based on the lower $\mathrm{IC}_{50}$ value; however, the HepG2 cells were sensitive to both $P$. kesiya extract and melphalan. A wide chemopreventive index was observed in the combination treatment, probably because the cytotoxic effect was lower in the normal Vero cells. P. kesiya extract's potent antiproliferation effect in the HepG2 cell line and high selective antiproliferation effect in both cancer cell lines requires further investigation. 

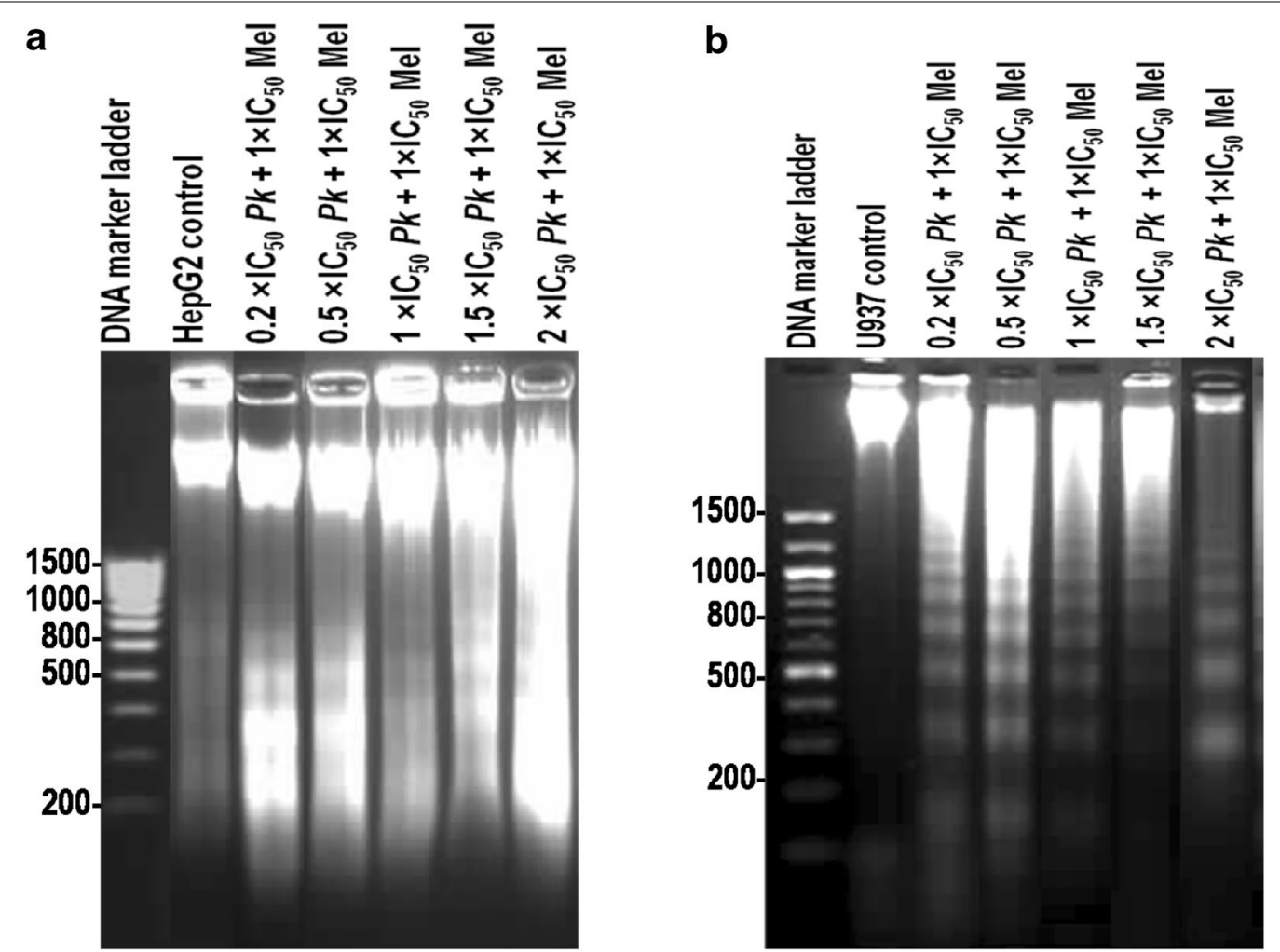

Fig. 2 DNA fragments after combination treatment of P. kesiya (Pk) extract with melphalan in HepG2 (a) and U937 (b) cell lines

Table 5 Identified compounds and their relative distribution in P. kesiya

\begin{tabular}{|c|c|c|}
\hline Retention time (min) & $\%$ of Total area & Assigned compounds \\
\hline 11.074 & 2.48 & $\begin{array}{l}\text { Pyrocatecol (1,2-benzenediol } \\
\text { or brenzcatechin) }\end{array}$ \\
\hline 16.412 & 2.66 & trans-Sobrerol \\
\hline 16.703 & 1.88 & Vanillin \\
\hline 29.551 & 1.55 & Palmitic acid \\
\hline 32.878 & 4.49 & Oleic acid \\
\hline 35.650 & 4.16 & Benzoyl isocyanate \\
\hline 36.096 & 4.77 & Pimaric acid \\
\hline 37.170 & 6.52 & Rosin acid \\
\hline 37.907 & 20.16 & $\begin{array}{l}\text { Podocarpa-8,11,13-trien-15- } \\
\text { oic acid, 13-isopropyl }\end{array}$ \\
\hline 38.525 & 4.31 & $\begin{array}{l}\text { 2,3-dimethoxy-5-[2-(3-hy- } \\
\text { droxy-4-methoxyphenyl) } \\
\text { ethenyl]phenol or Combret- } \\
\text { astatin A3 }\end{array}$ \\
\hline 41.788 & 5.98 & Neopine \\
\hline
\end{tabular}

GC-MS data of the $50 \%$ ethanol-water crude extract of P. kesiya

Drug and herb combinations could significantly decrease the toxicity and chemoresistance of drugs and increase their efficacy $[24,25]$ i.e., increasing the efficacy of the therapeutic effect; decreasing the dosage to avoid toxicity; reducing the development of drug resistance; and providing selective synergism against a target (or efficacy synergism) vs. host (or toxicity antagonism). The ability of herbal extracts to enhance anticancer activity might also arise from the potentiation of pharmacokinetics, wherein one ingredient enhanced the therapeutic effect of another (active ingredient or drug) by modulating its pharmacokinetic properties (i.e., absorption, distribution, metabolism, and/or excretion) $[24,25]$. The administration of multiple therapeutic agents is often associated with additional toxicities, which can be life threatening; however, a combination treatment with a non-toxic herbal extract like $P$. kesiya might provide superior benefits.

Previous work indicated that, in addition to the compounds identified here in P. kesiya extract (Table 5), gallic acid, chlorogenic acid, caffeic acid, vanillin, and coumaric acid in the $50 \%$ ethanol-water extract of $P$. kesiya exhibited an anticancer effect [14]. The main compounds found in various parts of Pinaceae were terpenes, such as $\alpha$ - and $\beta$-pinene [26]. Rosin is composed of a complex mixture of different compounds, including resin acids such as abietic acid, plicatic acid, and pimaric acid. Resin acids might be derived from terpenes 
through partial oxidation and undergo isomerization in the presence of strong acids or with heat [27]. Hence, terpenes such as $\alpha$ - and $\beta$-pinene might undergo thermal conversion into resin acids under the GC-MS condition studied. One previous study reported that $\alpha$-pinene expressed both apoptosis induction and antimetastatic activity against melanoma cells [26]. A previous work has also shown that citronellol-found in the family Pinaceae-inhibited an efflux P-gp protein at an $\mathrm{IC}_{50}$ value of $504 \mu \mathrm{M}[28]$.

\section{Conclusions}

Combining the $P$. kesiya extract with melphalan reduced toxicity while retaining the therapeutic efficacy (reduced approximately 4-9 fold) of melphalan.

\section{Abbreviations \\ DMEM: Dulbecco's modified Eagle's medium; DMSO: dimethylsulfoxide; FBS: fetal bovine serum; HepG2: human hepatocellular carcinoma cell line; NR: neu- tral red; PBS: phosphate buffer solution; NCl: National Cancer Institute (USA); U937: human leukemic cell line; Vero: normal African green monkey kidney epithelial cell line.}

\section{Authors' contributions}

NW designed the study. SM performed the experiments. NW and SM collected and analyzed data. SM, NW and SB analyzed and interpreted data. SM and NW wrote the manuscript. NW and SB revised manuscript. All the authors read and approved the final manuscript.

\section{Author details}

${ }^{1}$ Faculty of Pharmaceutical Sciences, Khon Kaen University, Khon Kaen 40002 , Thailand. ${ }^{2}$ Graduate School, Khon Kaen University, Khon Kaen 40002, Thailand. ${ }^{3}$ Faculty of Associated Medical Sciences, Khon Kaen University, Khon Kaen 40002, Thailand.

\section{Acknowledgements}

We thank (a) The Office of the Higher Education Commission, Thailand, under the Strategic Scholarships for Thai Doctoral Degree Programs (CHE-PhD-THARG 3/2549), (b) Khon Kaen University for financial support, (c)The authors thank the Plant Genetics Conservation Project under the Royal Initiation of her Royal Highness Princess Maha Chakri Sirindhorn, The Bureau of The Royal Household for permission to conduct the research and Electricity Generating Authority of Thailand (EGAT) for field support and (d) Mr. Bryan Roderick Hamman and Mrs. Janice Loewen-Hamman for assistance with the Englishlanguage presentation.

\section{Competing interests}

The authors declare that they have no competing interests.

Received: 8 November 2014 Accepted: 21 June 2016

Published online: 29 June 2016

\section{References}

1. Au JLS, Panchal N, Li D, Gan Y. Apoptosis: a new pharmacodynamic endpoint. Pharm Res. 1997;14:1659-71.

2. Lee C, Raffaghello L, Longo VD. Starvation, detoxification, and multidrug resistance in cancer therapy. Drug Resist Updates. 2012;15:114-22.

3. Pinmai K, Chunlaratthanabhorn S, Ngamkitidechakul C, Soonthornchareon N, Hahnvajanawong C. Synergistic growth inhibitory effects of Phyllanthus emblica and Terminalia bellerica extracts with conventional cytotoxic agents: doxorubicin and cisplatin against human hepatocellular carcinoma and lung cancer cells. World J Gastroentero. 2008;14:1491-7.

4. Tang SN, Singh C, Nall D, Meeker D, Shankar S, Srivastava RK. The dietary bioflavonoid quercetin synergizes with epigallocathechin gallate (EGCG) to inhibit prostate cancer stem cell characteristics, invasion, migration and epithelial-mesenchymal transition. J Mol Signal. 2010;5:14.

5. Wagner $\mathrm{H}$, Ulrich-Merzenich $\mathrm{G}$. Synergy research: approaching a new generation of phytopharmaceuticals. Phytomedicine. 2009;16:97-110.

6. Machana S, Weerapreeyakul N, Barusrux S, Thumanu K, Tanthanuch W. Synergistic anticancer effect of the extracts from Polyalthia evecta caused apoptosis in human hepatoma (HepG2) cells. Asian Pac J Trop Biomed. 2012;2:589-96.

7. Ya C, Ming-Hua Q, Kun G, Lin Z, ZhongRong L. A new abietane diterpenoid from the rosin of Pinus kesiya var. langbianensis (Pinaceae). Acta Botanica Yunnanica (ABY). 2006:3:323-5.

8. Jingkai D, Lisheng D, Yuanfen Y, Yu W, Handong S. Chemical constituents of the turpentine of Pinus kesiya var. langbianensis. Yunnan Zhiwu Yanjiu. 1983;5:224-46.

9. Koukos PK, Papadopoulou KI, Patiaka DT, Papagiannopoulos AD. Chemical composition of essential oils from needles and twigs of balkan pine (Pinus peuce Grisebach) grown in Northern Greece. J Agric Food Chem. 2000:48:1266-8.

10. Mateus EP, Gomesdasilva MD, Ribeiro AB, Marriott PJ. Qualitative mass spectrometric analysis of the volatile fraction of creosote-treated railway wood sleepers by using comprehensive two-dimensional gas chromatography. J Chromatogr. 2008;1178:215-22.

11. Mateus E, Baratab RC, Zrostlíková J, Gomesdasilva MDR, Paiva MR. Characterization of the volatile fraction emitted by Pinus spp. by one- and two-dimensional chromatographic techniques with mass spectrometric detection. J Chromatogr. 2010;1217:1845-55

12. Hiltunen R, Löyttyniemi K. Monoterpene composition of needle oil in Pinus kesiya Royle ex Gordon. Seloste: Pinus kesiya-männyn neulasöljyn monoterpeenikoostumus. Commun Inst For Fenn. 1978:94:1-9.

13. Hynniewta SR, Kumar Y. Herbal remedies among the Khasi traditional healers and village folk Mekhalaya. Indian J Traditional Knowl. 2008;7:581-6.

14. Machana S, Weerapreeyakul N, Barusrux S, Nonpanya A, Sripanidkulchai $B$, Thitimetharoch T. Cytotoxic and apoptotic effects of six herbal plants against the human hepatocarcinoma (HepG2) cell line. Chin Med. 2011;6:39.

15. Machana S, Weerapreeyakul N, Barusrux S, Thumanu K, Tanthanuch W. FTIR microspectroscopy discriminates anticancer action on human leukemic cells by extracts of Pinus kesiya; Cratoxylum formosum spp. pruniflorum and melphalan. Talanta. 2012:93:371-82.

16. Cloutier JF, Castonguay A, O'Connor TR, Drouin R. Alkylating agent and chromatin structure determine sequence context-dependent formation of alkylpurines. J Mol Biol. 2001;306:169-88.

17. Lialiaris T, Lyratzopoulos E, Papachristou F, Simopoulou M, Mourelatos C, Nikolettos N. Supplementation of melatonin protects human lymphocytes in vitro from the genotoxic activity of melphalan. Mutagenesis. 2008;23:347-54

18. Boegsted M, Holst JM, Fogd K, Falgreen S, Sørensen S, Schmitz A, Bukh A, Johnsen HE, Nyegaard K, Dybkaer K. Generation of a predictive melphalan resistance index by drug screen of B-cell cancer cell lines. PLOS ONE. 2011:6:e19322

19. Phengklai C. Pinaceae/Cephalotaxaceae/Cupressaceae. Flor Thail. 1972:2:193-6.

20. Phengklai C. Studies in flora of Thailand: Pinaceae. Thai For Bull. (Bot.). 1973;7:1-4.

21. Weerapreeyakul N, Nonpunya A, Barusrux S, Thitimetharoch T, Sripanidkulchai B. Evaluation of the anticancer potential of six herbs against a hepatoma cell line. Chin Med. 2012;7:15

22. Chou TC. Theoretical basis, experimental design, and computerized simulation of synergism and antagonism in drug combination studies. Pharmacol Rev. 2006;58:621-81.

23. Eid SY, El-Readi MZ, Wink M. Synergism of three-drug combinations of sanguinarine and other plant secondary metabolites with digitonin and doxorubicin in multi-drug resistant cancer cells. Phytomedicine. 2012;19:1288-97. 
24. Greco WR, Bravo G, Parsons JC. The search for synergy: a critical review from a response surface perspective. Pharmacol Rev. 1995;47:331-85.

25. Feng-Zhu JJ, Ma X, Cao ZW, Li YX, Chen YZ. Mechanisms of drug combinations from interaction and network perspectives. Nat Rev Drug Discov. 2009;8:111-28.

26. Matsuo AL, Figueiredo CR, Arruda DC, Pereira FV, Scutti JAB, Massaoka $\mathrm{MH}$, Travassos LR, Sartorelli P, Lago JHG. a-Pinene isolated from Schinus terebinthifolius Raddi (Anacardiaceae) induces apoptosis and confers antimetastatic protection in a melanoma model. Biochem Biophys Res Commun. 2011;411:449-54.
27. Parimal K, Khale A, Pramod K. Resins from herbal origin and a focus on their applications. IJPSR. 2011;2:1077-85.

28. Yoshida N, Takagi A, Kitazawa H, Kawakami J, Adachi I. Inhibition of P-glycoprotein-mediated transport by extracts of and monoterpenoids contained in Zanthoxyli Fructus. Toxicol Appl Pharm. 2005;209:167-73.

\section{Submit your next manuscript to BioMed Central and we will help you at every step:}

- We accept pre-submission inquiries

- Our selector tool helps you to find the most relevant journal

- We provide round the clock customer support

- Convenient online submission

- Thorough peer review

- Inclusion in PubMed and all major indexing services

- Maximum visibility for your research

Submit your manuscript at

www.biomedcentral com/submit 